\title{
Reactions of Microorganisms with Atomic Oxygen Radical Anions: Damage of Cells and Irreversible Inactivation
}

\author{
Longchun Li $\mathbb{D}^{1},{ }^{1}$ Fan $W u,{ }^{1}$ Yu Chen, ${ }^{1}$ Lei Xu, ${ }^{1}$ Xiaochang Hao, ${ }^{1}$ Yonghuan Chen, ${ }^{1}$ \\ Yixiang Sun $\mathbb{D}^{2}$, and Guoyin Xiong $^{3}$ \\ ${ }^{1}$ Department of Applied Chemistry, School of Science, Anhui Agricultural of University, Hefei, Anhui 230023, China \\ ${ }^{2}$ Soil and Fertilizer Institute of Anhui Academy of Agricultural Science, Hefei, Anhui 230001, China \\ ${ }^{3}$ Anhui JUKAI Agrochemical Co., LTD., Hefei, Anhui 230088, China
}

Correspondence should be addressed to Longchun Li; 1lch75@163.com and Yixiang Sun; sunyixiang@126.com

Received 18 July 2019; Accepted 28 August 2019; Published 3 November 2019

Guest Editor: Yunpan Ying

Copyright ( 2019 Longchun Li et al. This is an open access article distributed under the Creative Commons Attribution License, which permits unrestricted use, distribution, and reproduction in any medium, provided the original work is properly cited.

\begin{abstract}
Reactive oxygen species play important effects on organisms not only in vivo but also in vitro. The atomic oxygen radical anion $\left(\mathrm{O}^{-}\right)$ has shown extremely high oxidation and reactivity towards small molecules of hydrocarbons. However, the $\mathrm{O}^{-}$effects on cells of microorganisms are scarcely investigated. This work showed the evidence that $\mathrm{O}^{-}$could react quickly with microorganisms (Escherichia coli, Bacillus subtilis, Staphylococcus aureus, Aspergillus niger, Saccharomyces cerevisiae, and Actinomycetes (5046)) and damaged the cell walls seriously as well as their intrinsic structures, arising a fast and irreversible inactivation. SEM and TEM micrographs were used to reveal the structure changes of cells before and after reacting with $\mathrm{O}^{-}$radicals. The inactivation efficiencies of the microorganisms depended on the $\mathrm{O}^{-}$intensity, the initial population of microorganisms, the exposed area, the environment, and the microorganisms' types. Over $99 \%$ reduction of an initial $1.0 \times 10^{7}$ colony-forming unit (cfu), E. coli population only required less than 2 minutes while exposed to a $0.23 \mu \mathrm{A} / \mathrm{cm}^{2} \mathrm{O}^{-}$flux under dry argon atmosphere $\left(30^{\circ} \mathrm{C}, 1 \mathrm{~atm}\right)$. The observation of anionic intermediates $\left(\mathrm{CO}^{-}, \mathrm{CO}^{2-}, \mathrm{H}_{2} \mathrm{O}^{-}\right.$, and anionic hydrocarbons) by time-of-flight (TOF) mass spectrometry and the neutral volatile products $\left(\mathrm{CO}, \mathrm{CO}_{2}\right.$, and $\left.\mathrm{H}_{2} \mathrm{O}\right)$ by quadrupole mass spectrometry (Q-MS) provided an evidence of the reactions of $\mathrm{O}^{-}$with hydrocarbon bonds of the microorganisms. The inactivation mechanism of microorganisms induced by $\mathrm{O}^{-}$was discussed.
\end{abstract}

\section{Introduction}

Reactive oxygen species (ROS), such as the superoxide anion radical $\left(\mathrm{O}_{2}^{-}\right)$, the hydroxyl radical $(\mathrm{OH})$, and the singlet oxygen $\left({ }^{1} \mathrm{O}_{2}\right)$, are key chemical species in the biochemical processes and exert a very important effect on organisms [1-6]. Organisms can suffer lipid peroxidation, protein denaturation, DNA injuries, and enzyme inactivation by ROS [7-13]. Due to high reactivity of ROS, all the cellar components, lipids, proteins, nucleic acids, and carbohydrates may be damaged by their reactions with ROS, giving rise to metabolic and cellular disturbances or cell death [14-17]. There are increasing evidences showing that ROS are responsible for many diseases such as inflammation, lung injury, ischaemia-reperfusion injury, cancer, and aging [18-20]. On the other hand, ROS are not always harmful to organ- isms. For instance, ROS may be used as the intracellular signaling species for the introduction of defense gene expression and destroying malignant cells or tissue $[21,22]$.

Atomic oxygen radical anion $\left(\mathrm{O}^{-}\right)$is a monovalent anion (or monovalent negative ion) through the attachment of an electron to atomic oxygen $(\mathrm{O})$. At the same time, $\mathrm{O}^{-}$is also considered as a radical because it has an unpaired electron in its outermost orbit. It was found that atomic $\mathrm{O}^{-}$had extremely high oxidation and reactivity towards the hydrocarbons' small molecules [23-26]. Moreover, $\mathrm{O}^{-}$may be one of the most reactive oxygen species and therefore has various potential applications, such as a one-step synthesis of phenol from benzene [27], the reduction of NO [28], and the dissociation and oxidation of bio-oil $[29,30]$. Previously, our work showed that the $\mathrm{O}^{-}$could quickly react with the $B$. subtilis cells and seriously damage the cell walls as well as 
their other contents, leading to a fast and irreversible inactivation [31].

Herein, we investigated the $\mathrm{O}^{-}$effects on the microorganisms' inactivation (including the B. subtilis cells), the changes of cell structures caused by $\mathrm{O}^{-}$, and the products formed by the reaction of the microorganisms with $\mathrm{O}^{-}$. Our results demonstrate that $\mathrm{O}^{-}$can quickly react with the microorganisms, including Gram-positive bacteria (B. subtilis, S. aureus), Gram-negative bacteria (E. coli, B. A. niger), and fungi (S. cerevisiae, Actinomycetes (5046)), and seriously damage the cell walls and their intrinsic structures, leading to a fast and irreversible inactivation. The observed intermediates and volatile products provided an important evidence of the reactions of $\mathrm{O}^{-}$with hydrocarbon bonds of the microorganisms.

\section{Experimental Section}

2.1. $\mathrm{O}^{-}$Source. A sustainable and high-purity $\mathrm{O}^{-}$source was developed by using the microporous crystal $\left[\mathrm{Ca}_{24} \mathrm{Al}_{28} \mathrm{O}_{64}\right]^{4+} \cdot 4 \mathrm{O}^{-}$as an $\mathrm{O}^{-}$emitter $[32,33]$. We prepared the $\left[\mathrm{Ca}_{24} \mathrm{Al}_{28} \mathrm{O}_{64}\right]^{4+} \cdot 4 \mathrm{O}^{-}$crystal $\left(\mathrm{C} 12 \mathrm{~A} 7-\mathrm{O}^{-}\right)$by the solidstate reaction of $\mathrm{CaCO}_{3}$ and $\gamma-\mathrm{Al}_{2} \mathrm{O}_{3}$ (molar ratio of $\mathrm{CaC}$ $\left.\mathrm{O}_{3}: \gamma-\mathrm{Al}_{2} \mathrm{O}_{3}=12: 7\right)$ under dry oxygen atmosphere. The powder mixtures were pressed to a pellet and sintered at $1350^{\circ} \mathrm{C}$ for 18 hours under flowing dried oxygen. The sintered product was cooled to $430^{\circ} \mathrm{C}$ slowly at a rate of $\sim 10^{\circ} \mathrm{C} / \mathrm{min}$ and then quickly quenched to room temperature. Recently, a special characteristic of $\mathrm{C}^{2} \mathrm{~A} 7-\mathrm{O}^{-}$, emitting high intensity and purity $\mathrm{O}^{-}$, has been identified by our previous work $[32,33]$. The emitted species from the $\mathrm{C} 12 \mathrm{~A} 7-\mathrm{O}^{-}$surface were about $90 \% \mathrm{O}^{-}$and weak electron $(<10 \%)$. A reflective field was used to reflect the electrons. We controlled the beam intensity of $\mathrm{O}^{-}\left(0.01-2.0 \mu \mathrm{A} / \mathrm{cm}^{2}\right)$ by changing the temperature of the $\mathrm{C} 12 \mathrm{~A} 7-\mathrm{O}^{-}$sample and the ion extraction field.

2.2. Microorganisms' Preparation. The microorganisms investigated in our experiments were Gram-positive bacteria (B. subtilis, S. aureus), Gram-negative bacteria (E. coli, B. A. niger), and fungi (S. cerevisiae, Actinomycetes (5046)) which were purchased from China General Microbiological Culture Collection Center and maintained on nutrient agar slants at $5-6^{\circ} \mathrm{C}$. Before the inactivation experiments, microorganisms were harvested by centrifuging $\left(4000 \mathrm{rpm}, 4^{\circ} \mathrm{C}\right)$ for $10 \mathrm{~min}$ and the microorganisms' pellets were washed three times with sterile water. After pouring upper water, E. coli, B. subtilis, S. aureus, S. cerevisiae, and Actinomycetes (5046) were inoculated to L-broth (Bacto peptone $10 \mathrm{~g} / \mathrm{L}$, Bacto yeast extract $10 \mathrm{~g} / \mathrm{L}, \mathrm{NaCl} 5 \mathrm{~g} / \mathrm{L}, \mathrm{pH}=7.2$ ) and then incubated at $37^{\circ} \mathrm{C}$ on a shaking tray for 12 hours. A. niger was cultured in potato dextrose broth $(200 \mathrm{~g}$ peeled potato with a size of $\sim 4.0 \times 2.0 \times 2.0 \mathrm{~cm}^{3}$ were cooked in $1000 \mathrm{~mL}$ boiling distilled water for $8 \mathrm{~min}$. After passing through four lay cheesecloths, the broth was collected and $20 \mathrm{~g}$ of dextrose was added.) and incubated at $27^{\circ} \mathrm{C}$ on a shaking tray for 12 hours. The density of microorganisms was controlled at $10^{7} \sim 10^{8} \mathrm{cfu} / \mathrm{mL}$. Then, we transferred $0.1 \mathrm{~mL}$ resulted microorganisms to glass slide $(20 \mathrm{~mm} \times 20 \mathrm{~mm})$ for exposure to $\mathrm{O}^{-}$flux under the dry argon environment ( $1 \mathrm{~atm})$. All petri dishes and glass microscopy slides used for holding the microorganisms were first autoclaved at $125^{\circ} \mathrm{C}$ for $1 \mathrm{~h}$. The numbers of colonies on the slides before and after $\mathrm{O}^{-}$exposure were determined by the spread plate method with nutrient agar grown at $37^{\circ} \mathrm{C}$ for $12 \mathrm{~h}$.

E. coli spheroplasts were prepared by treating the intact E.coli cell suspension with $0.03 \mathrm{M}$ Tris- $\mathrm{HCl}$ buffer $(\mathrm{pH}=8.1)$ containing $20 \%$ sucrose with lysozyme $(1 \mathrm{mg} / \mathrm{mL})$ and EDTA (ethylenediaminetetraacetate, $0.1 \mathrm{M} \mathrm{pH}=7.0$ ) at $30^{\circ} \mathrm{C}$ for $60 \mathrm{~min}$ [34]. The treated cells were separated by centrifugation and resuspended in $0.2 \mathrm{M}$ phosphate buffer $(\mathrm{pH}=6.6)$ containing $0.2 \% \mathrm{MgCl}_{2}$ to form $E$. coli spheroplasts.

2.3. Inactivation Experiments. The experimental arrangement for measuring the inactivation efficiency and the reactions of microorganisms with $\mathrm{O}^{-}$was made up of three major parts: an $\mathrm{O}^{-}$radical source, a reaction chamber, and a product analysis system. The inactivation experiments were carried out in a cylindrical quartz reactor with a length of $60 \mathrm{~cm}$ and an inner diameter of $15 \mathrm{~cm}$. The microorganism samples prepared were maintained by Petri dishes or slides, which were supported by a copper dish. The inactivation experiments can be performed under different environmental conditions by flowing different gases (such as Ar, He, $\mathrm{N}_{2}, \mathrm{H}_{2} \mathrm{O}$, and $\mathrm{O}_{2}$ ). In order to study the atomic oxygen radical anion effects, all inactivation measurements were carried out in the dry argon environment. The reaction temperature was varied by cooling or heating copper dish with a watercycled system. The $\mathrm{O}^{-}$flux emitted from the $\mathrm{C} 12 \mathrm{~A} 7-\mathrm{O}^{-}$ sample was irradiated onto the microorganisms. The absolute $\mathrm{O}^{-}$ion flux was measured by a picoammeter and corrected by a TOF mass spectrometer. The numbers of colonies on the slides before and after $\mathrm{O}^{-}$exposure were determined by the spread plate method with nutrient agar grown at $37^{\circ} \mathrm{C}$ for $12 \mathrm{~h}$.

2.4. Reaction Product Analysis. For online analysis of reaction products, a time-of-flight (TOF) mass spectrometry and a quadrupole mass (Q-MS) spectrometry were connected to the reactor. A time-of-flight (TOF) mass spectrometer was used for measuring the anionic intermediates formed by the reactions of microorganisms with $\mathrm{O}^{-}$. The neutral products were detected by a quadrupole mass (Q-MS) spectrometry.

2.5. SEM and TEM Measurements. SEM (scanning electron microscopy) and TEM (transmission electron microscopy) experiments were performed to study the structural changes of cells before and after exposure to $\mathrm{O}^{-}$. The preparation of test samples was similar to the inactivation experiments mentioned above. After exposure to $\mathrm{O}^{-}$, the suspensions of E. coli were fixed with an equal volume of $3 \%$ glutaraldehyde buffered at $\mathrm{pH}=7.2$ with phosphate for about $1 \mathrm{~h}$. Then, the samples were centrifuged, and the resulting bacterial pellets were exposed overnight to additional phosphate-buffered $3 \%$ glutaraldehyde solution. The glutaraldehyde-fixed bacteria were embedded in $1 \%$ agar and washed with phosphate buffer. After that, the samples were fixed in buffered $1 \%$ osmium tetroxide in cacodylate buffer for $1 \mathrm{~h}$ at room temperature and then dehydrated by successive soakings in 50 , 70, 90, and $100 \%$ ethanol. The dried samples were rinsed 
twice with propylene oxide and infiltrated with propylene oxide-epoxy resin mixtures until the samples were in pure epoxy resin. Finally, the samples were placed in polyethylene capsules and resin polymerized at $60^{\circ} \mathrm{C}$ overnight [35]. Thin sections were cut using an ultracrotome and were mounted on 200 mesh copper grids and stained with uranyl acetate and lead citrate. The sections were examined with X-650 SEM (HITACHI) operating at $30 \mathrm{kV}$ and $\mathrm{H}-800$ TEM (HITACHI) operating at $100 \mathrm{kV}$.

\section{Results and Discussion}

3.1. Destruction of Cell Structures Caused by $O^{-}$. SEM and TEM micrographs were used to disclose any changes in the cell structures (the wall, the membrane, or the nucleoid) of the microorganisms induced by $\mathrm{O}^{-}$. Figures $1(\mathrm{a})$ and $1(\mathrm{~b})$ present the SEM photographs for E. coli cells before (Figure 1(a)) and after the $\mathrm{O}^{-}$exposure (Figure 1(b)). The irradiated cells appeared dramatically swollen and collapsed with a large amount of fragments, which were associated with the damages to the cell walls and subsequent lysis due to the $\mathrm{O}^{-}$irradiation. Figures 1(c) and 1(d) show the representative TEM micrographs of the initial (Figure 1(c)) and the $\mathrm{O}^{-}$-irradiated (Figure 1(d)) E. coli cells, respectively. The lighter part of the cell was the nuclear region containing some DNA fibrils and electron-dense ribosomes. The nucleoids after the exposure had contracted and a coarse precipitation of DNA appeared (Figure $1(\mathrm{~d})$ ), which indicated that $\mathrm{O}^{-}$might be able to penetrate the cells, and reacted with proteins or numerous enzymes involved in the control of DNA conformation in the nucleoids, resulting in the precipitation of DNA. Some of the cells appeared to be disrupted, and fragments of lysed cells were observed. The TEM results reveal that the secondary structure of the DNA-binding proteins of the cells was destroyed by the exposure to $\mathrm{O}^{-}$. These results are in good agreement with our earlier research [31].

3.2. $O^{-}$Effects on the Microorganisms' Inactivation. The correlation between the inactivation efficiency of the microorganisms and the $\mathrm{O}^{-}$intensity was also demonstrated by measuring the survival curves under different $\mathrm{O}^{-}$intensity. Figure 2(a) displays a series of survival diagrams under different $\mathrm{O}^{-}$intensity for $E$. coli intact cells, which exhibits biphasic curves (fast and slow processes). The decay of the survival numbers of $E$. coli cells, both in the fast and slow phases, depends on the $\mathrm{O}^{-}$intensity. On the other hand, the survival curves of E. coli spheroplasts in the fast processes are much different from those of $E$. coli intact cells (Figure 2(b)). The survival numbers of $E$. coli spheroplasts quickly decreased to the slow phases within $1 \mathrm{~min}$ while E. coli intact cells require about $5 \mathrm{~min}$ at the same condition. This result indicates that $\mathrm{O}^{-}$destroy cell walls firstly, which agree with the result by the SEM measurements.

For the biphasic inactivation processes, we deduce that during the first phase; the $\mathrm{O}^{-}$radicals react with the cell walls and form the volatile small molecules (such as $\mathrm{CO}, \mathrm{CO}_{2}$, and $\mathrm{H}_{2} \mathrm{O}$ ), resulting in quickly irreversible damage and lysis of the cells in the top layer (Figure 1(b)). As the microorganisms are killed in the first phase, the inactivated cells may stack

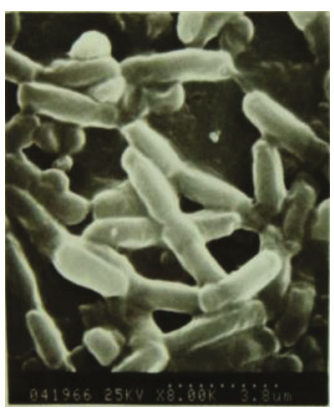

(a)

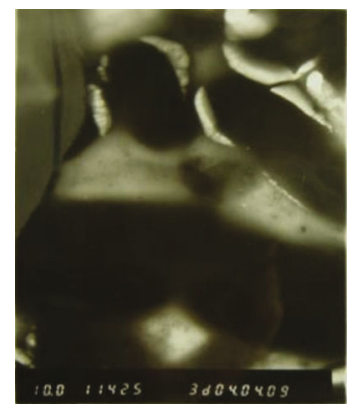

(c)

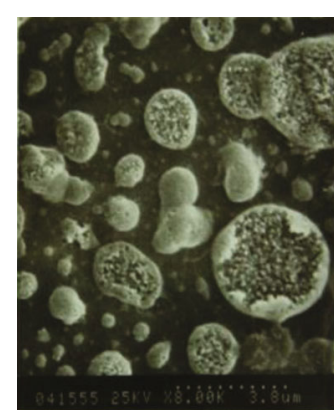

(b)

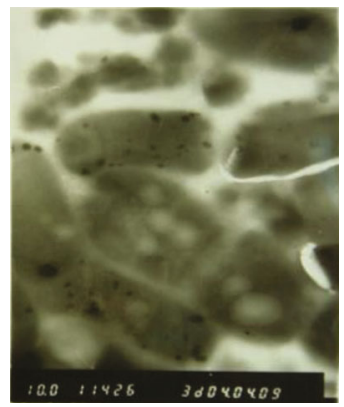

(d)
Figure 1: (a) SEM image of the initial E. coli cells (image size: $13.7 \times 11.4 \mathrm{~cm}^{2}$, initial number: $N_{0}=1.0 \times 10^{8} \mathrm{cfu} / \mathrm{mL}$ ). (b) $\mathrm{SEM}$ image of the exposed E. coli cells $\left(\mathrm{O}^{-}\right.$flux intensity: $192 \mathrm{nA} / \mathrm{cm}^{2}$, exposure time: $10 \mathrm{~min}$, and reaction temperature: $30^{\circ} \mathrm{C}$ ). (c) TEM image of the initial E. coli cells (image size: $7.4 \times 5.1 \mathrm{~cm}^{2}, N_{0}=5 \times$ $10^{7} \mathrm{cfu} / \mathrm{mL}$ ). (d) TEM image of the exposed E. coli cells $\left(\mathrm{O}^{-}\right.$flux intensity: $135 \mathrm{nA} / \mathrm{cm}^{2}$, exposure time: $10 \mathrm{~min}$, and reaction temperature: $30^{\circ} \mathrm{C}$ ).

and form an isolated layer. The occurrence of slow processes may be attributed to protection resulting from the contents of dead cells, which shielded the remaining survivors or aggregation during the treatment. The second phase, therefore, would mainly reflect the time required for sufficient erosion by reacting with the debris on the top layer.

$\mathrm{O}^{-}$effects on the other microorganisms' inactivation were also observed. As shown in Figure 3, the $\mathrm{O}^{-}$-induced inactivation efficiencies for B. subtilis, S. aureus, A. niger, S. cerevisiae, and Actinomycetes (5046) were also investigated. We found Actinomycetes (5046) were most resistant to the $\mathrm{O}^{-}$interaction, because Actinomycetes (5046) are terrestrial prokaryotes that grow mainly in mycelia and reproduce by spore. On the other hand, fungi (A. niger, S. cerevisiae) were easiest to inactivate in the same $\mathrm{O}^{-}$intensity. It appears that Gram-negative bacteria (E. coli) are more sensitive to $\mathrm{O}^{-}$than Gram-positive bacteria (B. subtilis, S. aureus). Thus, the inactivation efficiencies depend on the microorganisms' types, because the microorganisms with different components may have different resistant ability to $\mathrm{O}^{-}$.

Moreover, the inactivation efficiencies also depend on the reaction temperature and the exposure area. Figure 4 presents the survival curves of $E$. coli at different reaction temperature $\left(29^{\circ} \mathrm{C}, 34^{\circ} \mathrm{C}\right.$, and $\left.42^{\circ} \mathrm{C}\right)$. With elevatory reaction temperature, the inactivation efficiency of $E$. coli increases, which indicate that the inactivation process of $E$. coli by $\mathrm{O}^{-}$ 


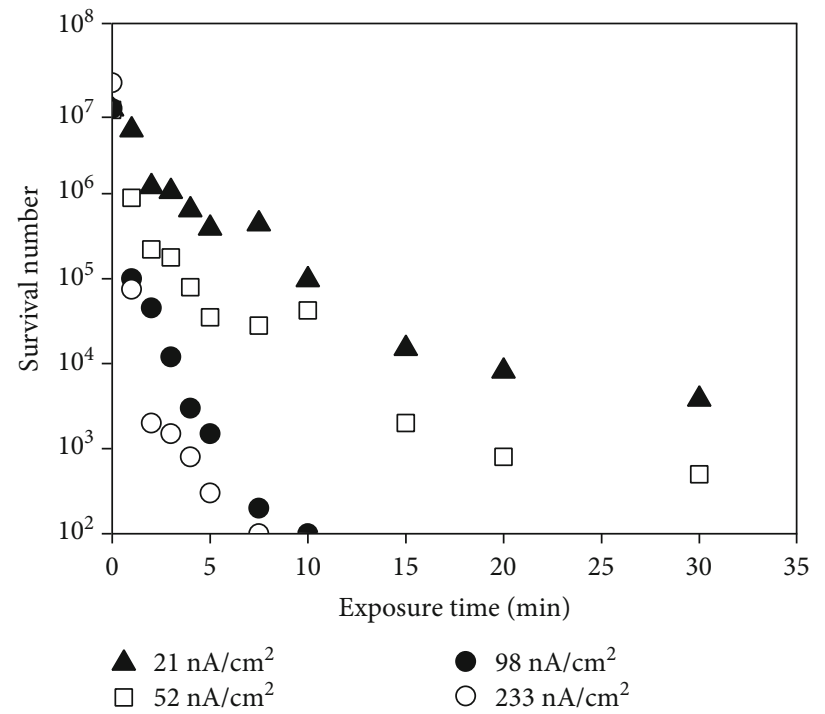

(a)

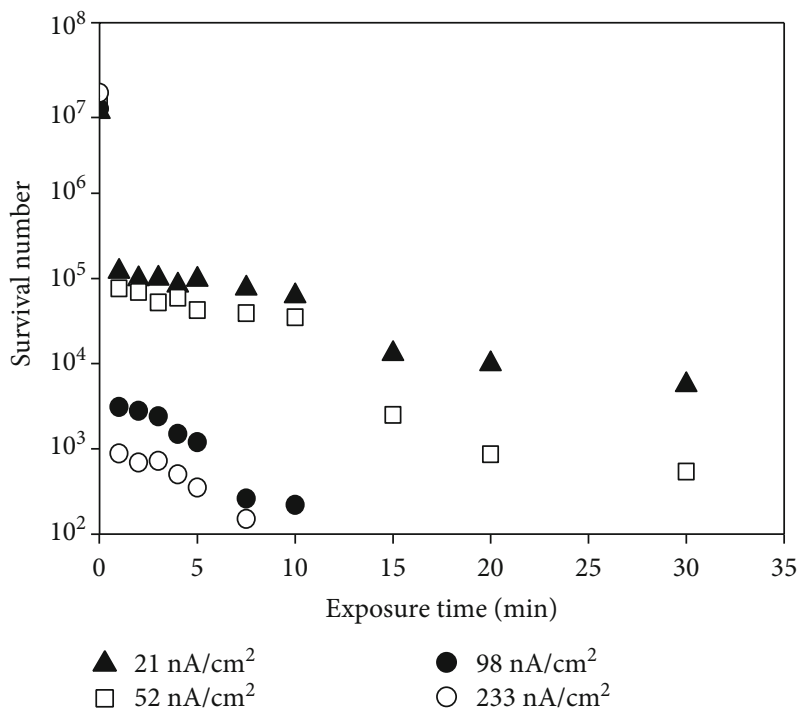

(b)

Figure 2: (a) Survival curves of $E$. coli cells $\left(N_{0}=1.0 \times 10^{7} \mathrm{cfu} / \mathrm{mL}\right)$ exposed to a series of $\mathrm{O}^{-}$flux intensity (exposure size: $\left.1.8 \mathrm{~cm}^{2}\right)$. (b) Survival curves of E. coli spheroplasts $\left(N_{0}=1.0 \times 10^{7} \mathrm{cfu} / \mathrm{mL}\right.$ ) exposed to a series of $\mathrm{O}^{-}$flux intensity (exposed size: $\left.1.8 \mathrm{~cm}^{2}\right)$, reaction temperature: $30^{\circ} \mathrm{C}$.

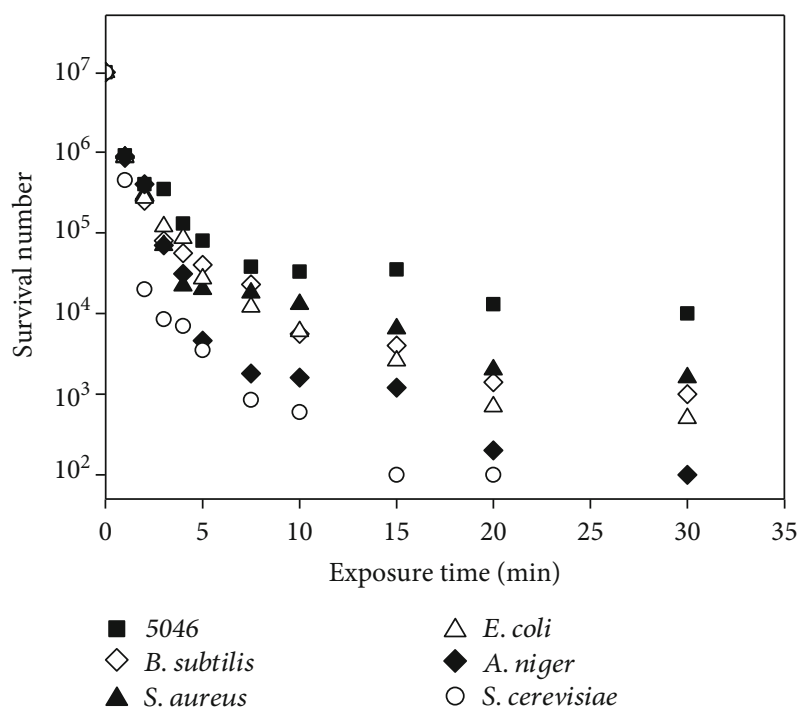

FIgURE 3: Survival curves of different types of microorganisms exposed to $\mathrm{O}^{-}:$B. subtilis, $S$. aureus, A. niger, E. coli, S. cerevisiae, and Actinomycetes (5046). $N_{0}: 1.0 \times 10^{7} \mathrm{cfu} / \mathrm{mL}, \mathrm{O}^{-}$flux intensity: $52 \mathrm{nA} / \mathrm{cm}^{2}$, reaction temperature: $30^{\circ} \mathrm{C}$, exposed size: $1.8 \mathrm{~cm}^{2}$.

is a thermally enhanced process. In addition, with enlarged exposure area, the inactivation efficiency also increases.

3.3. Products Formed by the Reaction of E. coli with $O^{-}$. The reaction products had been detected by the online analysis of the trail gases when $\mathrm{O}^{-}$is exposed onto the microorganisms. The anionic intermediates and the neutral products were detected by a time-of-flight spectrometry (TOF) and a quadrupole mass (Q-MS) spectrometry, respectively. Figure 5(a) displays a typical TOF spectrum for the $\mathrm{O}^{-} /$E. coli reaction sys-

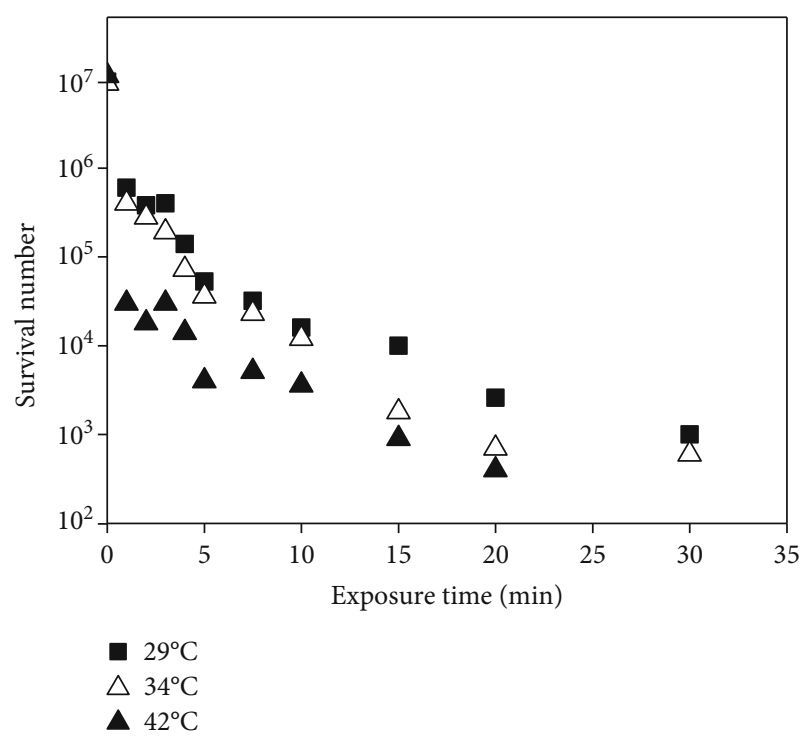

FIgURE 4: Reaction temperature effect on survival curves of E. coli exposed to $\mathrm{O}^{-}, N_{0}: 1.0 \times 10^{7} \mathrm{cfu} / \mathrm{mL}, \mathrm{O}^{-}$flux intensity: $52 \mathrm{nA} / \mathrm{cm}^{2}$, exposure size: $1.8 \mathrm{~cm}^{2}$.

tem. The anionic species of $\mathrm{H}^{-}, \mathrm{OH}^{-}, \mathrm{CO}^{-}, \mathrm{CO}_{2}^{-}, \mathrm{H}_{2} \mathrm{O}^{-}$, and anionic hydrocarbons were clearly identified (Figure 5(a)). In addition, the neutral products of $\mathrm{CO}, \mathrm{CO}_{2}$, and $\mathrm{H}_{2} \mathrm{O}$ were also observed by the Q-MS spectra (Figure 6(a)). It was also found that the peak intensities both for the anionic species and the neutral products increased with the increasing of the $\mathrm{O}^{-}$flux intensity (Figure 5(b) and Figure 6(b)). The microorganisms, briefly, are macromolecules mainly consisted of carbon, hydrogen, oxygen, and nitrogen atoms. Among these elements, carbon atom is the only one not self-associating to make volatile molecules such as $\mathrm{CO}$ and 


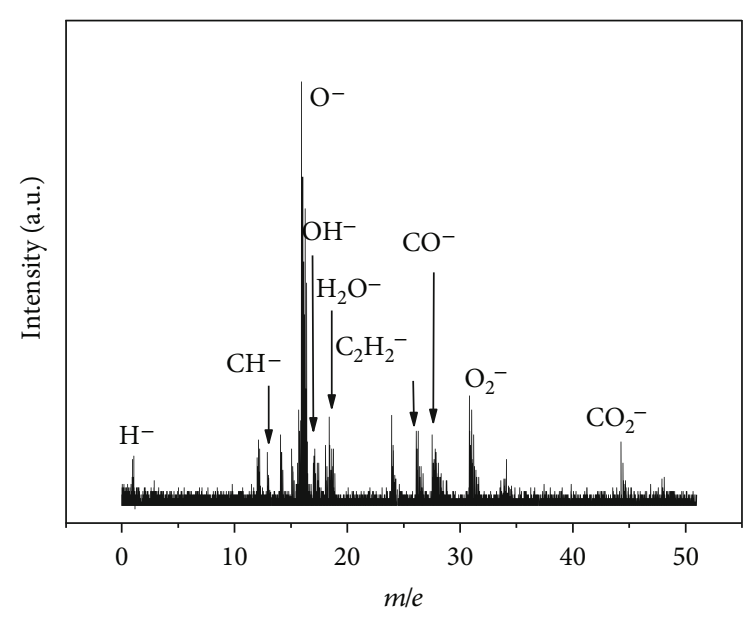

(a)

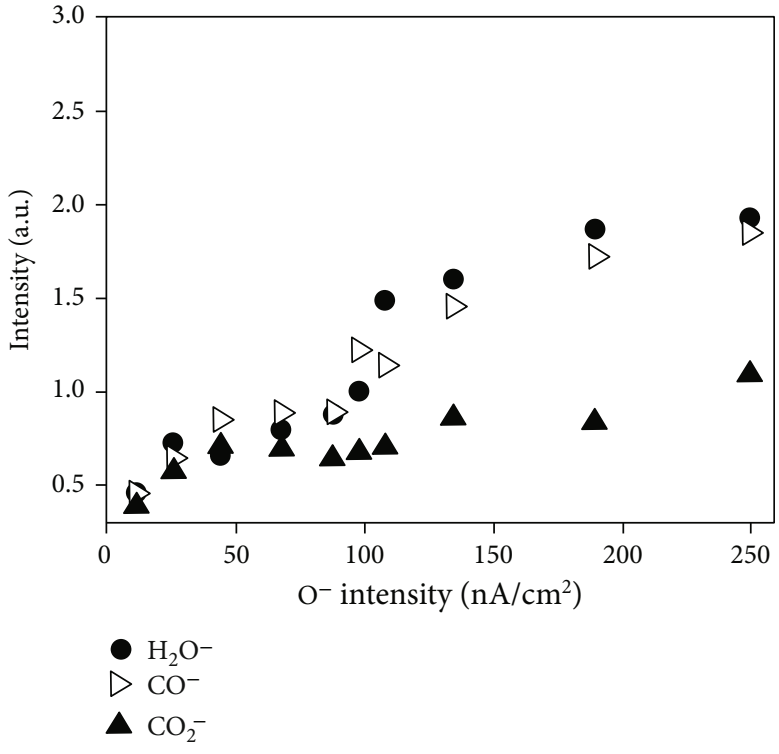

(b)

FIgURE 5: (a) Typical TOF spectrum shows the anionic intermediate species formed in the $\mathrm{O}^{-}$-induced inactivation processes $\left(\mathrm{O}^{-}\right.$: $250 \mathrm{nA} / \mathrm{cm}^{2}$ ). (b) The intensity changes of $\mathrm{H}_{2} \mathrm{O}^{-}, \mathrm{CO}^{-}$, and $\mathrm{CO}_{2}^{-}$with different $\mathrm{O}^{-}$intensity. Sample: E. coli, $N_{0}: 1.0 \times 10^{10} \mathrm{cfu} / \mathrm{mL}$, exposure size: $1.8 \mathrm{~cm}^{2}$.

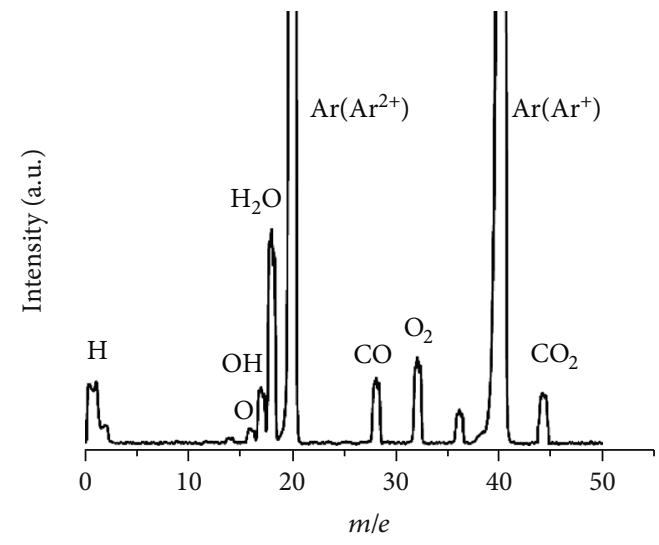

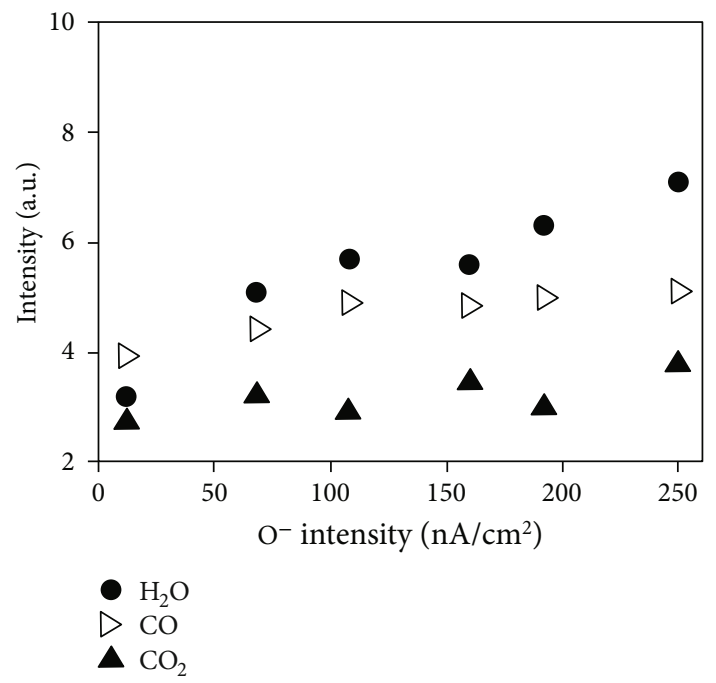

(b)

Figure 6: (a) Typical Q-MS spectrum shows that the volatile small molecules of $\mathrm{CO}, \mathrm{CO}_{2}$, and $\mathrm{H}_{2} \mathrm{O}$ were formed in the $\mathrm{O}^{-}$-induced inactivation processes $\left(\mathrm{O}^{-}: 250 \mathrm{nA} / \mathrm{cm}^{2}\right)$. (b) The intensity changes of $\mathrm{H}_{2} \mathrm{O}, \mathrm{CO}$, and $\mathrm{CO}_{2}$ with different $\mathrm{O}^{-}$intensity. Sample: E. coli, $N_{0}$ : $1.0 \times 10^{10} \mathrm{cfu} / \mathrm{mL}$, exposure size: $1.8 \mathrm{~cm}^{2}$.

$\mathrm{CO}_{2}$, and it must therefore form volatile compounds with other atoms in order to be removed from the cell surface. The released $\mathrm{CO}$ and $\mathrm{CO}_{2}$ would originate from the reactions of $\mathrm{O}^{-}$with hydrocarbon bonds of the microorganisms' cells. Based on the observations mentioned above, the active $\mathrm{O}^{-}$radical anions can react with the microorganisms, damage their cell structures, and finally result in a fast and irreversible inactivation. The inactivation mechanism of microorganisms induced by $\mathrm{O}^{-}$was schematically described in Figure 7.

\section{Conclusions}

The active $\mathrm{O}^{-}$radical anions possess high reactivity towards the microorganisms and damage the cell walls as well as their intrinsic structures, resulting in a fast and irreversible inactivation. The inactivation efficiencies depend on the $\mathrm{O}^{-}$flux intensity, the initial population of microorganisms, the exposed area, environment, as well as the microorganisms' types. The observation of anionic intermediates $\left(\mathrm{CO}^{-}, \mathrm{CO}_{2}{ }^{-}\right.$, $\mathrm{H}_{2} \mathrm{O}^{-}$, and anionic hydrocarbons) by time-of-flight (TOF) 


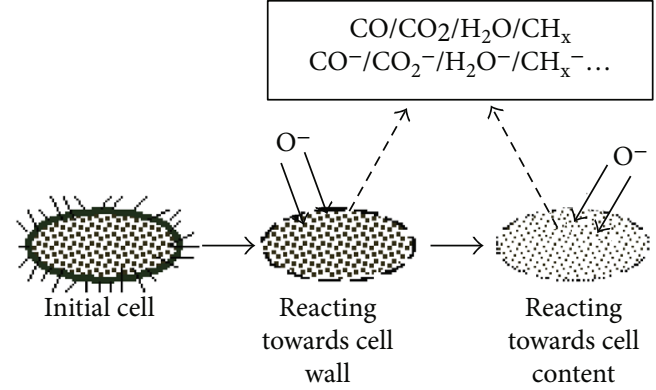

Figure 7: A schematic diagram shows the inactivation process induced by the $\mathrm{O}^{-}$reactions with the macromolecules of the outer wall and the inner content of the microorganism cell.

mass spectrometry and the neutral volatile products (CO, $\mathrm{CO}_{2}$, and $\mathrm{H}_{2} \mathrm{O}$ ) by quadrupole mass spectrometry (Q-MS) provided an evidence of the reactions of $\mathrm{O}^{-}$with hydrocarbon bonds of the microorganisms. We believe that the present approach would be extended to other fields such as the $\mathrm{O}^{-}$effects on lipid, protein, DNA, enzyme, and virus.

\section{Data Availability}

The data used to support the findings of this study are available from the corresponding authors upon request.

\section{Conflicts of Interest}

The authors declare no conflict of interest.

\section{Acknowledgments}

This study was financially supported by the Key Project of Natural Science Foundation of Universities in Anhui Province (KJ2017A137), the research fund of Anhui Agricultural University (Grant No. wd2018-03), finance support from the Project of School-Enterprise Cooperation (KJ20180142), and finance support from the Soil and Fertilizer Institute of Anhui Academy of Agricultural Sciences.

\section{References}

[1] S. Lenzen, "Chemistry and biology of reactive species with special reference to the antioxidative defence status in pancreatic $\beta$-cells," Biochimica et Biophysica Acta-General Subjects, vol. 1861, no. 8, pp. 1929-1942, 2017.

[2] M. S. Massima Mouele, O. O. Fatoba, O. Babajide, K. O. Badmus, and L. F. Petrik, "Review of the methods for determination of reactive oxygen species and suggestion for their application in advanced oxidation induced by dielectric barrier discharges," Environmental Science and Pollution Research International, vol. 25, no. 10, pp. 9265-9282, 2018.

[3] A. H. Paul, B. H. Daniel, U. S. Ingrid, G. C. Charles, K. Samuel, and V. Klaus, "Hydrogen peroxide as a potent bacteriostatic antibiotic: implications for host defense," Free Radical Biology \& Medicine, vol. 19, no. 1, pp. 31-37, 1995.

[4] Y. Yoko, U. Naoli, R. Akemi et al., "Active oxygen species generated from photoexcited fullerene $\left(\mathrm{C}_{60}\right)$ as potential medi- cines: $\mathrm{O}_{2}{ }^{-}$versus ${ }^{1} \mathrm{O}_{2}$," Journal of the American Chemical Society, vol. 125, no. 42, pp. 12803-12809, 2003.

[5] Y. Ma, B. Wang, R. Zhang et al., "Initial simulated acid rain impacts reactive oxygen species metabolism and photosynthetic abilities in Cinnamonum camphora undergoing high temperature," Industrial Crops and Products, vol. 135, pp. 352-361, 2019.

[6] M. E. Orczykowski, S. M. Calderazzo, E. Shobin et al., "Cell based therapy reduces secondary damage and increases extent of microglial activation following cortical injury," Brain Research, vol. 1717, pp. 147-159, 2019.

[7] Q. S. Freya and R. B. Garry, "Acidic pH amplifies ironmediated lipid peroxidation in cells," Free Radical Biology \& Medicine, vol. 28, no. 8, pp. 1175-1181, 2000.

[8] S. Kawanishi, Y. Hiraku, and S. Oikawa, "Mechanism of guanine-specific DNA damage by oxidative stress and its role in carcinogenesis and aging," Mutation Research/Reviews in Mutation Research, vol. 488, no. 1, pp. 65-76, 2001.

[9] Y. S. Kim, M. J. Kang, and Y. M. Cho, "Low production of reactive oxygen species and high DNA repair: mechanism of radioresistance of prostate cancer stem cells," Anticancer Research, vol. 33, no. 10, pp. 4469-4474, 2013.

[10] P. Gaudu, V. Nivière, Y. Pétillot, B. Kauppi, and M. Fontecave, "The irreversible inactivation of ribonucleotide reductase from Escherichia coli by superoxide radicals," FEBS Letters, vol. 387, no. 2-3, pp. 137-140, 1996.

[11] J. A. Escobar, M. A. Rubio, and E. A. Lissi, "SOD and catalase inactivation by singlet oxygen and peroxyl radicals," Free Radical Biology \& Medicine, vol. 20, no. 3, pp. 285-290, 1996.

[12] M. J. Davies, "Singlet oxygen-mediated damage to proteins and its consequences," Biochemical Biophysical Research Communications, vol. 305, no. 3, pp. 761-770, 2003.

[13] X. W. Yue and V. T. Andreas, "Impact of fungicides on active oxygen species and antioxidant enzymes in spring barley (Hordeum vulgare L.) exposed to ozone," Environmental Pollution, vol. 116, no. 1, pp. 37-47, 2002.

[14] V. Antonio and M. Julio, "Reactive oxygen species induce different cell death mechanisms in cultured neurons," Free Radical Biology \& Medicine, vol. 36, no. 9, pp. 1112-1125, 2004.

[15] F. Julia, D. Vadim, H. F. B. John et al., "Reactive oxygen species produced by NADPH oxidase regulate plant cell growth," Nature, vol. 422, no. 6930, pp. 442-446, 2003.

[16] J. Aikens and T. A. Dix, "Perhydroxyl radical (HOO.) initiated lipid peroxidation: the role of fatty acid hydroperoxides," The Journal of Biological Chemistry, vol. 266, no. 23, pp. 1509115098, 1991.

[17] E. R. Stadtman, "Protein oxidation and aging," Science, vol. 257, no. 5074, pp. 1220-1224, 1992.

[18] C. M. Martinez, "Oxygen free radicals and human disease," Biochimie, vol. 77, no. 3, pp. 147-161, 1995.

[19] J. M. McCord, "Superoxide radical: a likely link between reperfusion injury and inflammation," Advances in Free Radical Biology \& Medicine, vol. 29, no. 2, pp. 325-345, 1986.

[20] J. L. Marx, "Oxygen free radicals linked to many diseases," Science, vol. 235, no. 4788, pp. 529-531, 1987.

[21] J. M. Matés and F. M. Sánchez-Jiménez, "Role of reactive oxygen species in apoptosis: implications for cancer therapy," International Journal of Biochemistry \& Cell Biology, vol. 32, no. 2, pp. 157-170, 2000.

[22] N. Yuji, T. Tomohisa, I. Hiroshi et al., "A novel potent inhibitor of inducible nitric oxide inhibitor, ONO-1714, reduces 
intestinal ischemia-reperfusion injury in rats," Nitric Oxide, vol. 10, no. 3, pp. 170-177, 2004.

[23] W. H. Wang, W. Feng, W. L. Wang, and P. Li, “Ab initio molecular dynamics simulation study on the stereo reactions between atomic oxygen anion and methane," Molecules, vol. 23, no. 10, pp. 1-13, 2018.

[24] J. Ma, B. Xu, X. J. Meng et al., "Reactivity of atomic oxygen radical anions bound to titania and zirconia nanoparticles in the gas phase: low-temperature oxidation of carbon monoxide," Journal of the American Chemical Society, vol. 135, no. 8, pp. 2991-2998, 2013.

[25] L. Tian, J. Meng, X. Wu et al., "Reactivity of oxygen radical anions bound to scandia nanoparticles in the gas phase: C-H bond activation," Chemistry-A European Journal, vol. 20, no. 4, pp. 1167-1175, 2014.

[26] J. Lee and J. J. Grabowski, "Reactions of the atomic oxygen radical anion and the synthesis of organic reactive intermediates," Chemical Reviews, vol. 92, no. 7, pp. 1611-1647, 1992.

[27] T. Dong, J. Li, F. Huang et al., "One-step synthesis of phenol by $\mathrm{O}^{-}$and $\mathrm{OH}^{-}$emission material," Chemical Communications, vol. 21, pp. 2724-2726, 2005.

[28] A. M. Gao, X. Zhu, H. Wang et al., "Reduction features of NO over a potassium-dope C12A7- $\mathrm{O}^{-}$catalyst," Journal of Physical Chemistry B, vol. 110, no. 24, pp. 11854-11862, 2006.

[29] Z. Wang, T. Dong, L. Yuan et al., "Characteristics of bio-oilsyngas and its utilization in Fischer-Tropsch synthesis," Energy Fuels, vol. 21, no. 4, pp. 2421-2432, 2007.

[30] Z. Wang, Y. Pan, T. Dong et al., "Production of hydrogen from catalytic steam reforming of bio-oil using $\mathrm{C}_{12 \mathrm{~A} 7-\mathrm{O}^{-} \text {-based }}$ catalysts," Applied Catalysis A: General, vol. 320, pp. 24-34, 2007.

[31] L. Li, L. Wang, Z. Yu, X. Lv, and Q. Li, "Inactivation of Bacillus subtilis by atomic oxygen radical anion," Plasma Science and Technology, vol. 9, no. 1, pp. 119-124, 2007.

[32] Q. Li, H. Hosono, M. Hirano et al., "High-intensity atomic oxygen radical anion emission mechanism from $12 \mathrm{CaO} \cdot 7 \mathrm{Al}_{2} \mathrm{O}_{3}$ crystal surface," Surface Science, vol. 527, no. 1, pp. 100-112, 2003.

[33] Q. Li, K. Hayashi, M. Nishioka et al., "Absolute emission current density of $\mathrm{O}^{-}$from $12 \mathrm{CaO} \cdot 7 \mathrm{Al}_{2} \mathrm{O}_{3}$ crystal," Applied Physics Letters, vol. 80, no. 22, pp. 4259-4426, 2002.

[34] S. Kayano, W. Toshiya, and H. Kazuhito, "Studies on photokilling of bacteria on $\mathrm{TiO}_{2}$ thin film," Journal of Photochemistry and Photobiology A: Chemistry, vol. 156, no. 1-3, pp. 227233, 2003.

[35] H. Chen, S. Chan, J. C. Lee, C. Chang, M. Murugan, and R. W. Jack, "Transimission elctron microscopic observations of membrane effects of antibiotic cecropin B on Escherichia coli," Microscopy Research and Technique, vol. 62, no. 5, pp. 423430, 2003. 


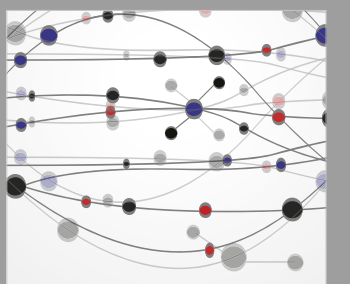

The Scientific World Journal
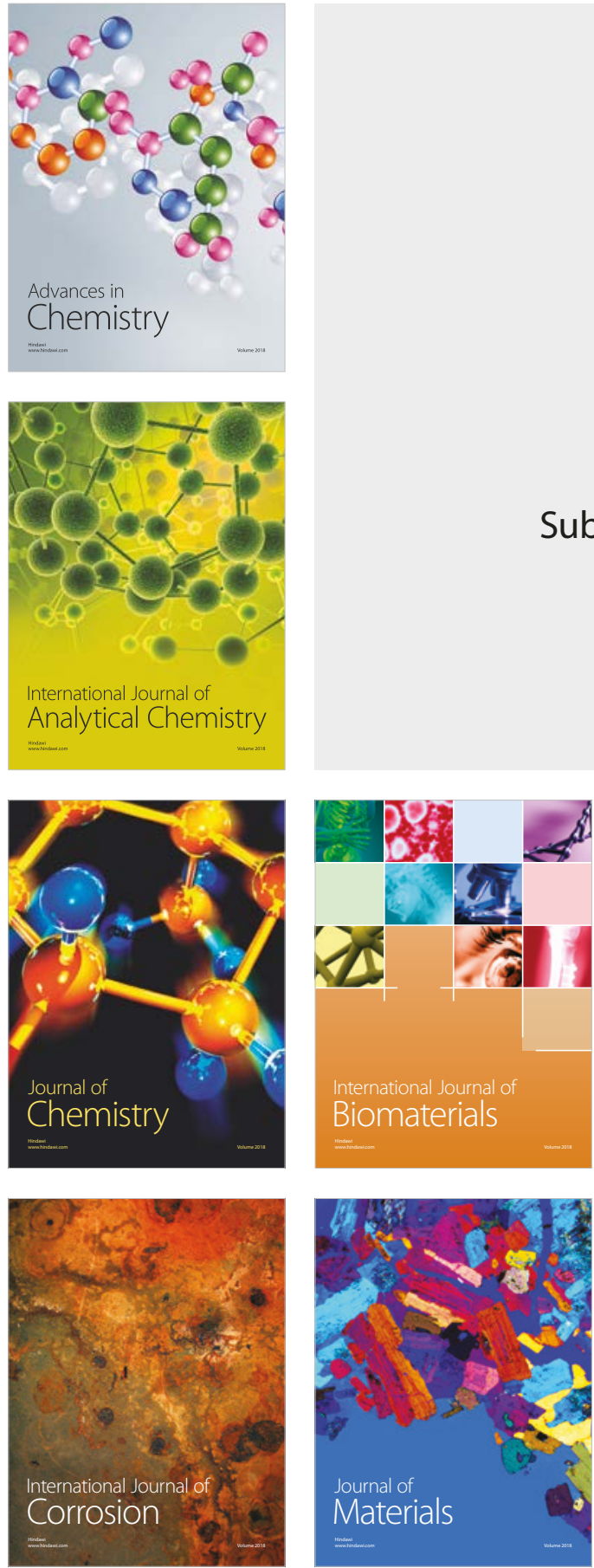

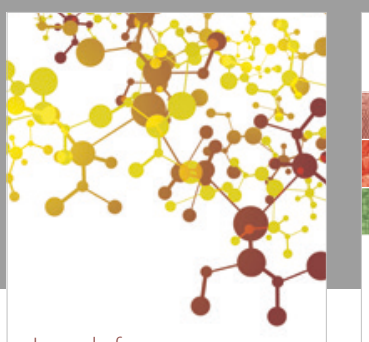

Journal of

Applied Chemistry
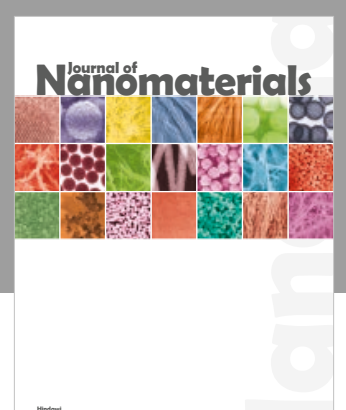

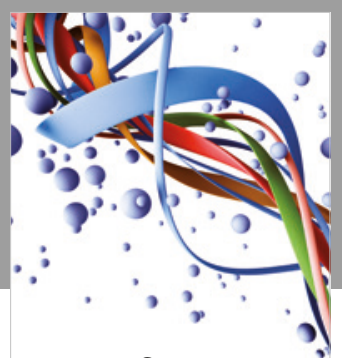

Scientifica

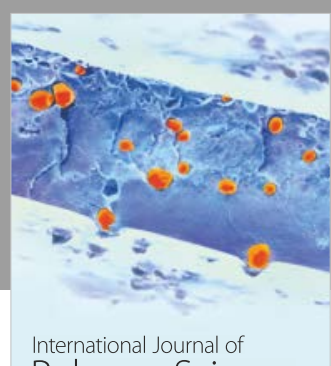

Polymer Science

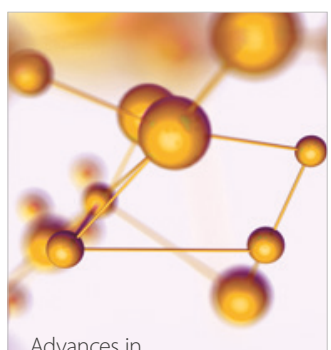

Physical Chemistry
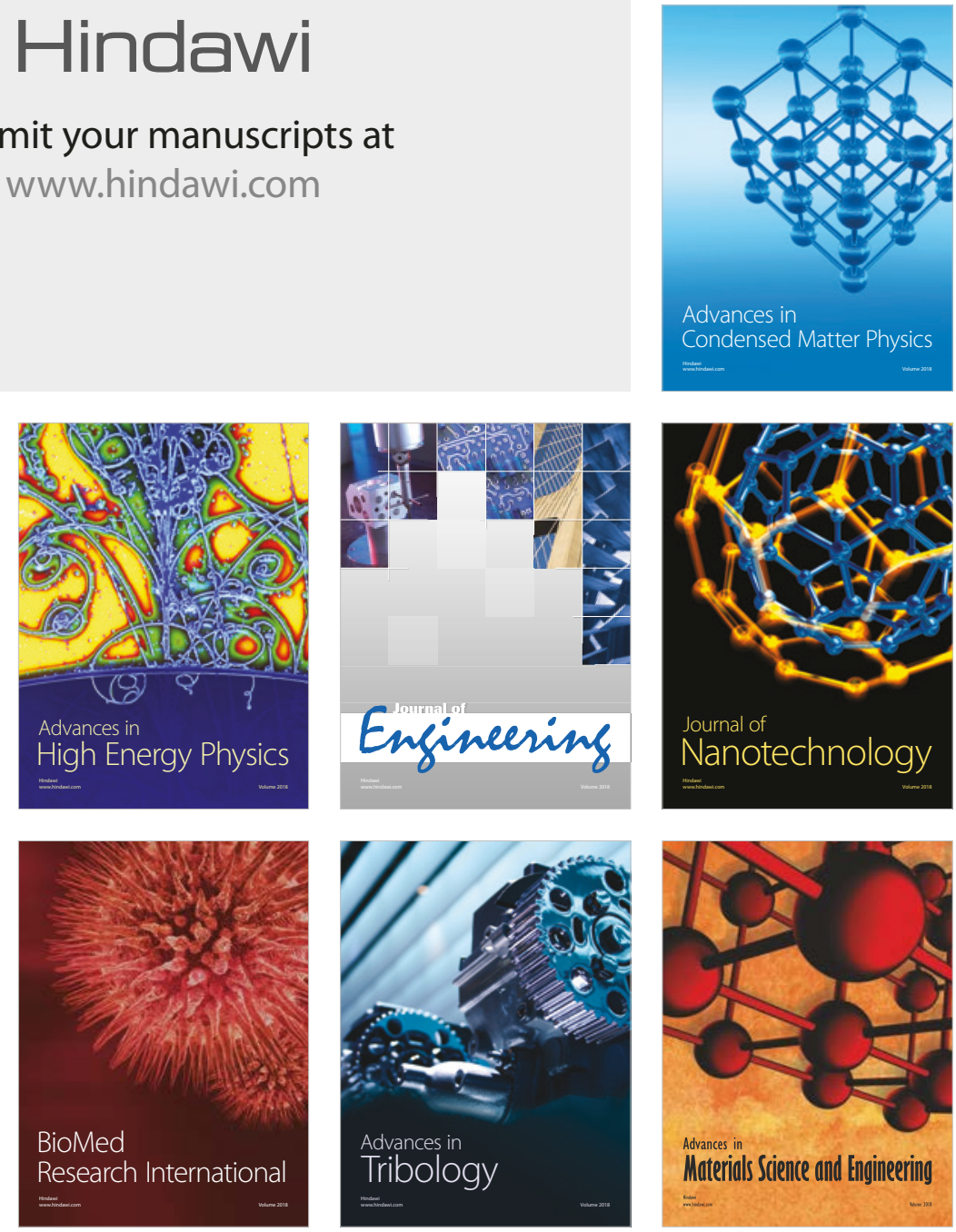